\title{
Literature Review: Social Determinant of Health in Breast Cancer Patients Survival
}

\author{
Azriful Azriful*(D), Fatmawaty Mallapiang (D), Yessy Kurniati(D) \\ Lecturer of Public Health Study Program, Faculty of Medicine and Health Sciences, Universitas Islam Negeri Alauddin, \\ Makassar, Indonesia
}

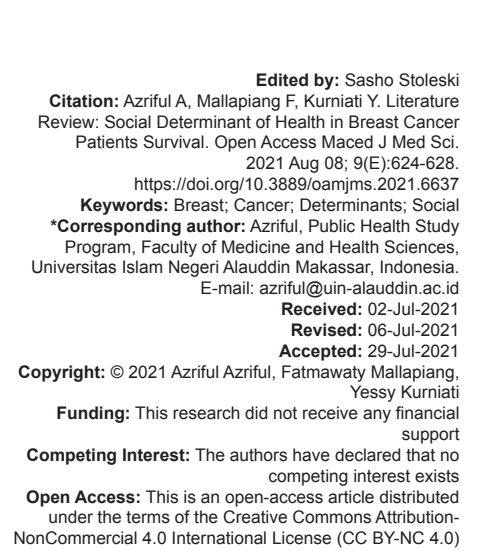

Abstract

BACKGROUND: Social determinants have an important role in the survival of breast cancer patients.

AIM: This article aims to reviews the social determinants that affect the survival of breast cancer patient

METHODS: We searched PubMed and Google Scholar for identifying studies related to this review using free-text terms and Medical Subject Headings terms. Both experimental and observational studies on social determinants of breast cancer patient survival which were published in the English language have been included in this review except expert opinions, commentaries, editorials, and review articles. Ten studies were eligible to be included in review.

RESULTS: Social health determinants that play a role in the survival of breast cancer patients are education level, place of residence, socioeconomic status, social environment, racial discrimination, and access to health services.

CONCLUSION: Social determinants have an influence on the survival of breast cancer patients, so it is important to pay attention to these factors.

\section{Introduction}

Cancer is a huge burden worldwide, especially for people in poor and developing countries. The incidence of cancer is increasing due to population growth and aging, as well as the increasing prevalence of risk factors such as smoking, poor diet, physical inactivity, and reproductive changes [1].

Inequities in the survival of breast cancer sufferers are mostly caused by inequities in health services, including differences in access to early detection, ease of access, and quality of care for breast cancer patients. The gap is caused by a combination of factors including health literacy, lack of cultural fit, and difficulty of access due to socioeconomic status or geographic remoteness [2].

Emotional support is an important determinant of the mental well-being of cancer survivors. Low emotional support is an apparent risk factor for anxiety and depression [3]. Socio-economic status also has an impact on survival [4].

Cancer patients who are unable to access health services have a 5.95 times risk of experiencing delays in conducting initial screening for breast cancer sufferers. They can not access health services because of their low incomes. They are afraid of the cost of breast examinations [5].

The social determinants of health are the conditions in which a person is born, grows, works, lives, and ages as well as a number of rules and systems that govern people's lives [6]. The gap in the social determinants of health of breast cancer patients is an important factor in the survival of breast cancer patients. This social health determinant is related to the early detection of breast cancer. By knowing the determinants of health problems, prevention efforts can be made for high-risk breast cancer sufferers. This article reviews the social determinants that affect the survival of breast cancer patient.

\section{Materials and Methods}

\section{Search strategy}

This literature review was conducted using the 2015 Preferred Reporting Items for Systematic Reviews and Meta-Analysis guidelines [7]. The review begins by 
creating a glossary of word relevant to Medical Subject Headings keywords and keyword sub-headings that are generated and used to search for comprehensive peerreviewed articles from the computerized bibliographic databases of PubMed and Google Scholar.

The search includes research conducted in the world and published between January 2016 and December 2020. Articles extracted from each database are imported into the Mendeley Library. The combination of keywords used in the search was as follows: (Social determinant * OR determinant of health * OR determinant factor), (Risk Factor * OR determinant * OR correlate * OR cause *), (Model * analysis *), and (Survival * Breast Cancer ${ }^{*}$ ).

\section{Inclusion and Exclusion Criteria}

The research criteria included in this review are if the research: Focuses on women with breast cancer; analyze the social health determinants that affect the survival of breast cancer patients (Survival of Breast Cancer); Published between 2016 and 2020; Written in English, the data were analyzed using the multivariate regression model, multilevel analysis model, predictive model, and classification tree analysis, Cox proportional hazards models (qualitative studies, case studies, books, policy briefs or theses excluded from review); Published in a peerreviewed journal (non-peer-reviewed studies, reviews or comments are excluded).

\section{Data Extraction}

All articles identified by the search are exported to the Mendeley Library and duplicates are removed. Furthermore, all publications were screened by reading the titles and abstracts. In the final screening phase, the full text was read of the remaining articles and retained the studies that met the inclusion/exclusion criteria. All data extraction and study assessments taken were assessed independently. A summary of selected studies is recorded, this includes; authors, year of publication, country of study, number and age of women patients who were sampled, social health determinants that affect the survival of breast cancer patients, and analysis model. The results are as shown in Table 1.

\section{Results}

A total of 133 articles were taken from one database. After the deletion of duplicates, 118 articles were retained. Based on the results of the title screening, 23 articles were issued. Abstracts of the 95 articles
Table 1: Determinan social of health in the studies

\begin{tabular}{|c|c|c|c|c|}
\hline Analysis model & Author & $\begin{array}{l}\text { Research } \\
\text { sites }\end{array}$ & $\begin{array}{l}\text { Number of } \\
\text { Samples }\end{array}$ & $\begin{array}{l}\text { Social determinants } \\
\text { that affect the } \\
\text { survival of breast } \\
\text { cancer sufferers }\end{array}$ \\
\hline $\begin{array}{l}\text { Multivariate linear } \\
\text { regression }\end{array}$ & $\begin{array}{l}\text { (Yan } \\
\text { et al. - 2016) }\end{array}$ & Cina & 1160 woman & $\begin{array}{l}\text { Social support and } \\
\text { financial planning }\end{array}$ \\
\hline $\begin{array}{l}\text { Flexible } \\
\text { Parametric } \\
\text { Models equivalent } \\
\text { to Cox regression }\end{array}$ & $\begin{array}{l}\text { (Brooke } \\
\text { et al., 2017) }\end{array}$ & Swedia & $\begin{array}{l}14.231 \text { woman, } \\
\text { age } 65-79 \text { year, } \\
\text { have children } \\
\text { aged } \geq 30 \text { years. }\end{array}$ & $\begin{array}{l}\text { Children's education } \\
\text { level }\end{array}$ \\
\hline $\begin{array}{l}\text { The Cox } \\
\text { proportional } \\
\text { hazard model } \\
\text { and parametric } \\
\text { models }\end{array}$ & $\begin{array}{l}\text { (Mohseny } \\
\text { et al., 2016) }\end{array}$ & Iran & $\begin{array}{l}797 \text { breast } \\
\text { cancer patients, } \\
\text { aged } 25-93 \\
\text { years. }\end{array}$ & $\begin{array}{l}\text { Education level and } \\
\text { residence }\end{array}$ \\
\hline $\begin{array}{l}\text { Tapered } \\
\text { Multivariate } \\
\text { Matching }\end{array}$ & $\begin{array}{l}\text { (Silber } \\
\text { et al., 2018) }\end{array}$ & Pennsylvania & $\begin{array}{l}1,890 \text { non- } \\
\text { Hispanic white, } \\
1,824 \text { black, and } \\
723 \text { Hispanic } \\
\text { women }\end{array}$ & $\begin{array}{l}\text { Socioeconomic } \\
\text { Status }\end{array}$ \\
\hline $\begin{array}{l}\text { Log rank test; } \\
\text { Kaplan-Meier and } \\
\text { Cox Regression } \\
\text { in SPSS; PH } \\
\text { assumption by } \\
\text { STATA }\end{array}$ & $\begin{array}{l}\text { (Heidarnia } \\
\text { et al., 2017) }\end{array}$ & $\begin{array}{l}\text { "The Cancer } \\
\text { Research } \\
\text { Center of } \\
\text { Shohada- } \\
\text { E-Tajish } \\
\text { Hospital". }\end{array}$ & $\begin{array}{l}797 \text { patients } \\
\text { with breast } \\
\text { cancer, with age } \\
\text { classifications } \\
\text { ranging from } \\
25-93 \text { years }\end{array}$ & $\begin{array}{l}\text { Childhood } \\
\text { conditions, } \\
\text { residence, } \\
\text { education level } \\
\text { and age }\end{array}$ \\
\hline $\begin{array}{l}\text { Poisson } \\
\text { generalized } \\
\text { linear model and } \\
\text { flexible parametric } \\
\text { survival model }\end{array}$ & $\begin{array}{l}\text { (Bower } \\
\text { et al., 2018) }\end{array}$ & $\begin{array}{l}\text { Stockholm } \\
\text { and Gotland } \\
\text { Region, } \\
\text { Sweden }\end{array}$ & $\begin{array}{l}26.913 \text { cases of } \\
\text { breast cancer } \\
\text { and } 133,361 \\
\text { in the Swedish } \\
\text { Control group } \\
\text { from } 1992 \text { to } \\
2012\end{array}$ & $\begin{array}{l}\text { Socioeconomic } \\
\text { Status }\end{array}$ \\
\hline $\begin{array}{l}\text { Prospective and } \\
\text { retrospective }\end{array}$ & $\begin{array}{l}\text { (Puigpinos- } \\
\text { Riera } \\
\text { et al., 2018) }\end{array}$ & $\begin{array}{l}\text { Barselona, } \\
\text { Spanyol }\end{array}$ & $\begin{array}{l}2712 \text { Women } \\
\text { with cancer> } 18 \\
\text { years }\end{array}$ & $\begin{array}{l}\text { Emotional support } \\
\text { and low social } \\
\text { class, social } \\
\text { isolation, and age }\end{array}$ \\
\hline $\begin{array}{l}\text { Multivariable } \\
\text { Cox Proportional } \\
\text { Hazards } \\
\text { Regression } \\
\text { Models }\end{array}$ & $\begin{array}{l}\text { (Beyer et al., } \\
\text { 2016) }\end{array}$ & $\begin{array}{l}\text { Southeastern } \\
\text { Wisconsin, } \\
\text { Milwaukee } \\
\text { and Racine }\end{array}$ & 2828 woman & $\begin{array}{l}\text { Racial } \\
\text { discrimination }\end{array}$ \\
\hline $\begin{array}{l}\text { Cox Regression } \\
\text { Modelling }\end{array}$ & $\begin{array}{l}\text { (Tin et al., } \\
2018 \text { ) }\end{array}$ & New Zealand & 13,657 patient & $\begin{array}{l}\text { Differences in } \\
\text { access to health } \\
\text { services }\end{array}$ \\
\hline $\begin{array}{l}\text { Multivariate Cox } \\
\text { Proportional } \\
\text { Hazard }\end{array}$ & $\begin{array}{l}\text { (Lee et al., } \\
\text { 2019) }\end{array}$ & Korea & 27.141 patient & $\begin{array}{l}\text { Residence and level } \\
\text { of education }\end{array}$ \\
\hline
\end{tabular}

produced were read and filtered so that 42 articles were excluded. A further 53 full-text articles were read and 28 articles were excluded. 25 articles met the inclusion criteria. A bibliographic reference manual search of the stored articles identified an additional five articles for a total of 10 studies as shown in Figure 1.

Based on the results of the review of the article, it can be identified the social health determinants that affect the survival of breast cancer patient. These factors are education level, place of residence, socioeconomic status, social environment, racial discrimination, and access to health services.

Patients with academic degrees have a higher survival time compared to patients with high school education [8]. Women with higher levels of education show a commitment to running more frequent routine check-ups so that they can detect cancer as early as possible. Education is related to the stage of cancer at diagnosis [9]. The level of education of the adult patient's child can contribute to the maternal survival after being diagnosed with breast cancer. Mothers or women who have less educated children may need extra social support [10]. 


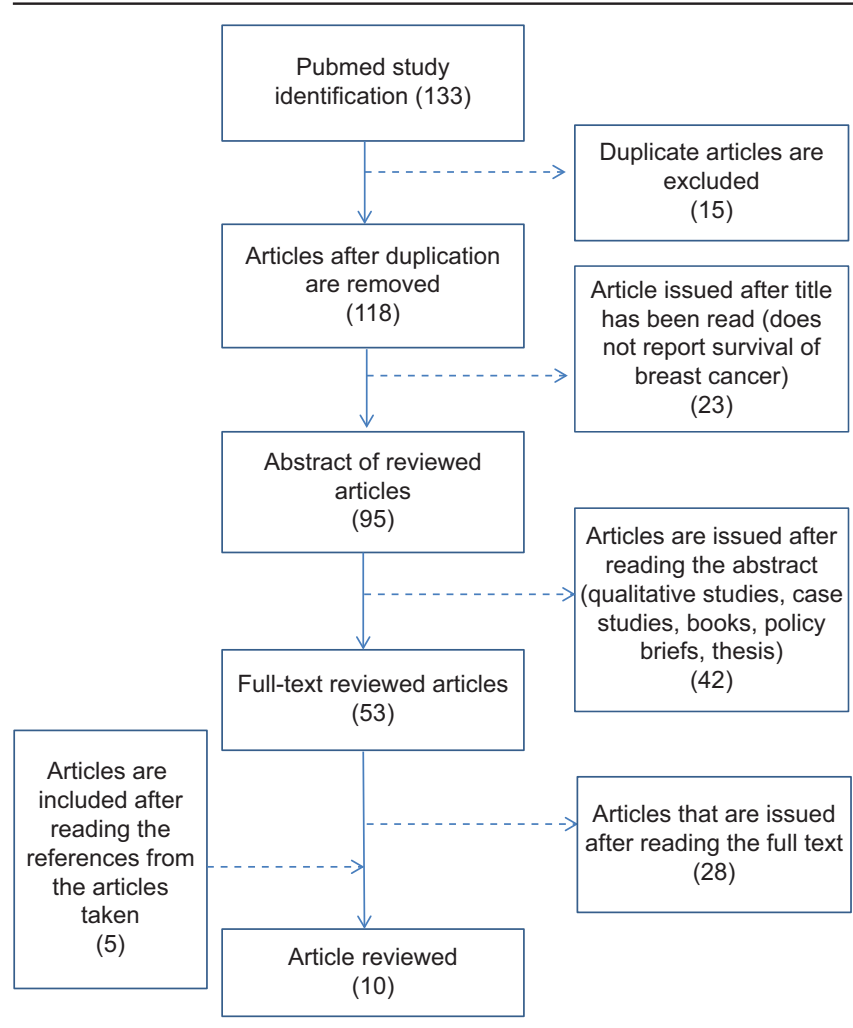

Figure 1: Flow chart of the Study based on the PRISMA 2015 Guidelines

Childhood environmental conditions are related to health conditions in adulthood [11]. Poor environmental conditions, associated with breast cancer survivability [9]. Social health determinants such as age, education level, and place of residence (regency municipality), as well as socioeconomic status also affect the survival rate of sufferers [8]. Urban areas are more rapidly diagnosed and their outcomes are better than patients living in rural areas [12].

Socioeconomic status is related to social class and income levels across racial and ethnic groups. Patients with low socioeconomic status have a worse impact (utilization of health services, survival and quality of life, and advanced disease) due to breast cancer patients with high socioeconomic status [13]. The breast cancer patient with high economic status has a high survival rate and lower mortality rate compared to low low socioeconomic groups [3]. Social environments such as social support, social isolation, poverty, poor environmental conditions, and unemployment affect the trajectory of breast cancer patients. Survival factors related to socioeconomic status include income and education levels, poor environmental conditions, unemployment, racial discrimination, support, and social networks [9]. High household income is associated with a better quality of life than breast cancer sufferers in each of the measured domains. Higher socioeconomic status has been associated with many aspects of better care od sufferers, such as proper care, access to comprehensive rehabilitation, taking time off from work, and reducing concerns about financial constraints [14]. Low emotional support and social isolation are risk factors for anxiety and depression in cancer patients. This can lead to worsening of the patient's condition [3].

The downtown environment does not accept the patient's mortgage which results in an increase in cancer sufferers specifically, a decrease in quality and survival, and an increase in the number of cases of death. The existence of discrimination in mortgage rights harms the health of cancer sufferers. Discrimination in access to health care, levels of stress, and differences in socioeconomic status greatly contribute to the inability to unravel the risk of chronic disease and health inequalities [15]

Another determinant factor found was the type of Health Insurance. This type of health insurance is directly related to the burden of medical care costs. Support from family, friends, neighbors is very influential in significantly increasing the quality of life for breast cancer sufferers. Higher household incomes, lowpaying medical insurance plans, and traditional Chinese medicine have a good impact on the quality of life for breast cancer survivors [12]. Other factors including environmental deprivation, method of diagnosis, type of health care facility, ability. reaching primary cancer treatment centers, and the type of locoregional therapy is a major contributor to ethnic differences in the survival of breast cancer patients [16]

\section{Discussion}

The results of the review show that the social determinants that affect the survival of breast cancer are education level, place of residence, socioeconomic status, social environment, racial discrimination, and access to health services.

The level of education can affect the survival of cancer sufferers because the level of education provides a higher awareness to carry out prevention and treatment activities. Women with higher levels of education are more concerned about having mammography and pap tests [17]. Survival is related to the initial screening performed by cancer survivors [18].

Breast cancer mortality is higher in women aged $<50$ years and less educated [19]. The findings, in Poland, show that breast cancer mortality is higher in women with primary education [20]. Other findings suggest that people with low levels of education are more prone to experiencing hopelessness and cognitive impairment [21]

Where they live as child and adolescents affects a person's diet. This diet is one of the risks for breast cancer and is associated with patient survival. One study found that women living in coastal areas had a lower incidence of breast cancer than urban women. This is related to the high fish consumption among women in 
coastal areas [22]. However, if it is related to the time of diagnosis of breast cancer, which is a factor that greatly affects patient survival, women who live in urban areas are diagnosed with the disease more quickly [23]. This causes them to receive treatment more quickly and to have a higher survival rate than women living in rural. However, studies in postmenopausal women, it was not found that there was an effect of residence on the time of the first diagnosis [24].

Socioeconomic status affects the treatment of breast cancer sufferers. Including geographic areas [25]. Residents in metropolitan areas have better disease improvement rates as well as lower mortality rates. Cancer patients living [26] in urban areas have a higher survival rate than patients from rural areas [27].

The social environment affects health behavior by influencing norms, patterns of social control, and supporting the formation of certain environments and behaviors. The social environment can trigger stress. Slum environments, high crime rates, dense, and poor housing can trigger chronic psychosocial stress. Racism and discrimination affect the system in society, including education and employment [14].

Patients who have private insurance follow endocrine therapy longer than patients who pay for themselves [28]. This is of course related to the burden of payments that must be made by patients. Insurance helps medical costs for breast cancer patients and increases patient survival

\section{Study Limitation and Novelty}

This study uses a recent study so the results are quite new findings. In addition, most of the studies used are population-based studies with a large enough sample size and fairly good data analysis. The limitation of this study is that the search source are still limited to open access, thus limiting the number of studies reviewed.

\section{Conclusion}

Social determinants of health that play a role in the survival of breast cancer patients are education level, place of residence, socioeconomic status, social environment, racial discrimination, and access to health services. These factors influence patient survival through mechanisms, such as influencing willingness to do early disease screening, quality of life, psychosocial stress, access to early diagnosis and treatment, and willingness to follow the therapy process. This finding is an alarm to pay attention to patients who have these determinant factors so that prevention and treatment efforts can be more focused on these patients.
A structured efforts is needed to overcome the influence of social determinants on breast cancer patients so that the survival rate can be increased.

\section{References}

1. Torre LA, Bray FB, Siegel RL, Ferlay J, Lortet J, Jemal A. Global cancer statistics, 2012. CA Cancer J Clin. 2015;65(2):87-108. https://doi.org/10.3322/caac.21262

PMid:25651787

2. Seneviratne S, Campbell I, Scott N, Shirley R, Peni T, Lawrenson R. Ethnic differences in breast cancer survival in New Zealand: Contributions of differences in screening, treatment, tumor biology, demographics and comorbidities. Cancer Causes Control. 2015;26(12):1813-24. https://doi. org/10.1007/s10552-015-0674-5

PMid:26407955

3. Puigpinós-Riera R, Graells-Sans A, Serral G, Continente X Bargalló $\mathrm{X}$, Domènech $\mathrm{M}$, et al. Anxiety and depression in women with breast cancer: Social and clinical determinants and influence of the social network and social support (DAMA cohort). Cancer Epidemiol. 2018;55:123-9. https://doi. org/10.1016/j.canep.2018.06.002

PMid:29940418

4. McKenzie F, Jeffreys M. Do lifestyle or social factors explain ethnic/racial inequalities in breast cancer survival? Epidemiol Rev. 2009;31(1):52-66. https://doi.org/10.1093/epirev/mxp007 PMid:19675112

5. Dyanti GA, Suariyani NL. Factors delaying breast cancer patients in conducting an initial examination to health services. Public Health Journal, 2016; 11(2):278-84. Https://doi.org/10.15294/ kemas

6. World Health Organization. World Conference on Socia Determinant of Health: Case Studies on Social Determinan. Geneva: World Health Organization. https://www.who.int/ sdhconference/resources/case_studies/en. [Last accessed on 2021 Mar 14].

7. Moher D, Shamseer L, Clarke M, Ghersi D, Liberatî A Petticrew M, et al. Preferred reporting items for systematic review and meta-analysis protocols (PRISMA-P) 2015 statement. Syst Rev. 2015;4(1):1. https://doi.org/10.1186/2046-4053-4-1 PMid:25554246

8. Mohseny M, Amanpour F, Mosavi-Jarrahi A, Jafari H, MoradiJoo M, Monfared ED. Application of Cox and parametric survival models to assess social determinants of health affecting three-year survival of breast cancer patients. Asian Pac J Cancer Prev. 2016;17(Suppl 3):311-6. https://doi.org/10.7314/ APJCP.2016.17.S3.311

PMid:27165244

9. Coughlin SS. Social determinants of breast cancer risk, stage, and survival. Breast Cancer Res Treatment. 2019;177(3):53748. https://doi.org/10.1007/s10549-019-05340-7 PMid:31270761

10. Brooke HL, Weitoft GR, Talbäck M, Feychting M, Ljung R. Adult children's socioeconomic resources and mothers' survival after a breast cancer diagnosis: A Swedish population-based cohort study. BMJ Open. 2017;7(3):e014968. https://doi.org/10.1136/ bmjopen-2016-014968 PMid:28363931

11. Heidarnia MA, Mohseny M, Amanpour F, Joo MM, Jarrahi AM, Monfared ED. Relationship of social determinants of health 
with the three-year survival rate of breast cancer. Asian Pac J Cancer Prev. 2017;18(4):1121-6. https://doi.org/10.22034/ APJCP.2017.18.4.112

PMid:28547951

12. Lee JS, Kim HA, Cho SH, Lee HB, Park MH, Jeong J, et al. Five-year overall survival of interval breast cancers is better than non- interval cancers from Korean breast cancer registry. Asian Pac J Cancer Prev. 2019;20(6):1717-26. https://doi. org/10.31557/APJCP.2019.20.6.1717 PMid:31244292

13. Silber JH, Rosenbaum PR, Ross RN, Reiter JG, Niknam BA, Hill AS, et al. Disparities in breast cancer survival by socioeconomic status despite medicare and medicaid insurance. Milbank $Q$. 2018;96(4):706-54. https://doi.org/10.1111/1468-0009.12355 PMid:30537364

14. Yan B, Yang LM, Hao LP, Yang C, Quan L, Wang LH, et al. Determinants of quality of life for breast cancer patients in Shanghai, China. PLoS One. 2016;11(4):e0153714. https://doi. org/10.1371/journal.pone. 0153714 PMid:27082440

15. Beyer KM, Zhou Y, Matthews K, Bemanian A, Laud PW, Nattinger AB. New spatially continuous indices of redlining and racial bias in mortgage lending: Links to survival after breast cancer diagnosis and implications for health disparities research. Health Place. 2016;40:34-43. https://doi.org/10.1016/j. healthplace.2016.04.014

PMid:27173381

16. Lee JS, Kim HA, Cho SH, Lee HB, Park MH, Jeong J, et al. Five-year overall survival of interval breast cancers is better than non- interval cancers from Korean breast cancer registry. Asian Pac J Cancer Prev. 2019;20(6):1717-26. https://doi. org/10.31557/APJCP.2019.20.6.1717 PMid:31244292

17. Tin ST, Elwood JM, Brown C, Sarfati D, Campbell I, Scott N, et al. Ethnic disparities in breast cancer survival in New Zealand: Which factors contribute? BMC Cancer. 2018;18(1):58. https:// doi.org/10.1186/s12885-017-3797-0 PMid:29310606

18. Damani G, Basso D, Acampora A, Bianchi CB, Silvrestini G, Frisicale EM, et al. The Impact of level education on adherence to breast and cervical cancer screening: Evidence from a systematic review and meta analysis. Prev Med. 2015;81:2819. https://doi:10.1016/j.ypmed.2015.09.011 PMid:26408405

19. Akinyemiju T, Ogunsina $\mathrm{K}$, Sakhuja $\mathrm{S}$, Ogbhodo $\mathrm{V}$ Braithwaite D. Life-course socioeconomic status and breast and cervical cancer screening: Analysis of the WHO's Study on global ageing and adulth health (SAGE). BMJ Open. 2016;6:11. doi:10.1136/bmjopen-2016-012753

20. Trewin CB, Strand BH, Weedon-Fekjaer H, Ursin G. Changing pattermsof breast cancer incidence and mortality by education level over four decades in Norway, 1971-2009. Eur J Public Health. 2017;27(1):160-6. https://doi.org/10.1093/eurpub/ckw148 PMid:28177482

21. Burzynsca M, Maniecka-Bryla I, Pikala M. Trends of mortality due to breast cancer in Poland, 2000-2016. BMC Public Health. 2020;20:120. https://doi.org/10.1186/s12889-020-8256-1

22. Calderon C, Gomez D, Carmona-Bayonas A, Hernandez R, Ghanem I, GilRaga M, et al. Social support, coping strategies and sociodemographic factors in woman with breast cancer. Clin Transl Oncol. 2021;2021:2592. https://doi.org/10.1007/ s12094-021-02592-y

PMid:33840046

23. Haralddottir A, Steingrimsdottir L, Valdimarsdottir UA, Aspelund T, Tryggvadottir L, Harris TB, et al. Early life residence, fish consumption and risk of breast cancer. Cancer Epidemiol Biomarkers Prev. 2017;26(3):346-54. https://doi. org/10.1158/1055-9965.EPI-16-0473-T

\section{PMid:27765796}

24. Williams F, Thompson E. Disparity in breast cancer late stage at diagnosis in Missouri: does rural versus urban residence matter? J Rac Ethnic Health Disparities. 2016;3(2):233-9. https://doi.org/10.1007/s40615-015-0132-9 PMid:27271063

25. Sealy-Jefferson S, Roseland ME, Cote ML, Lehman A, Whitsel EA, Mustafaa FN, et al. Rural-urban residence and stage at breast cancer diagnosis among postmenopausal woman: The woman's health initiative. J Womans Health. 2019;28(2):27683. https://dx.doi.org/10.1089\%2Fjwh.2017.6884 PMid:30230942

26. Dreyer MS, Nattinger AB, McGinley EL, Pezzin EL. Socioeconomic status and breast cancer treatment. Breast Cancer Res Treat. 2017;167(1):1-8. https://doi.org/10.1007/ s10549-017-4490-3 PMid:28884392

27. Afshar N, English DR, Milne RC. Rural-urban residence and cancer survival in high-income countries: A systematic review. Cancer. 2019;125(13):2172-84. https://doi.org/10.1002/ cncr.32073 PMid:30933318

28. Obeng-Gyasi S, Timsina L, Bhattacharyya $\mathrm{O}$, Fisher $\mathrm{CL}$, Haggstrom DA. Breast cancer presentation, surgical management and mortality across the rural urban continuum in the national cancer database. Ann Surg Oncol. 2020;27(6):180515. https://doi.org/10.1245/s10434-020-08376-y PMid:32206955

29. Sadigh G, Gray RJ, Sparano JA, Yanez B, Garcia SF, Timsina LR, et al. Breast cancer patient's insurance status and residence zip code correlate with early discontinuation of endocrine therapy: An analysis of the ECOG-ACRIN TAILORx trial. Cancer 2021;127(14):2545-52. https://doi.org/10.1002/cncr.33527 PMid:33793979 